\title{
ANALISIS NILAI TAMBAH USAHA PEMBUATAN TAHU DI DESA PAOWAN KECAMATAN PANARUKAN KABUPATEN SITUBONDO
}

\author{
Puryantoro $^{1}$; Abdul Wafi ${ }^{2}$ \\ 1puryantorounars@gmail.com \\ ${ }^{1,2}$ Universitas Abdurachman Saleh Situbondo
}

\begin{abstract}
Abstrak
Tujuan yang ingin dicapai dalam penelitian ini adalah untuk mengetahui besar nilai tambah yang diperoleh dari usaha pembuatan tahu pada UD.Haji Imam Buhori di Desa Paowan Kecamatan Panarukan.Penentuan daerah penelitian dilakukan secara sengaja (Purposive Method) Metode penelitian yang digunakan adalah analisis diskriptif.Nilai tambah yang diperoleh pada usaha pembuatan tahu pada UD. Haji Imam Buhori di Desa Paowan dianalisis dengan metode hayami. Hasil penelitian menunjukkan bahwa nilai tambah yang diperoleh pengusaha dalam produksi tahu sebesar Rp 1.712,- per papan tahu, keuntungan pengusaha dalam produksi tahu sebesar Rp 412,- per papan tahu dan sisanya sebesar Rp 1.300 per papan tahu merupakan imbalan tenaga kerja.
\end{abstract}

Kata kunci : nilai tambah, tahu, hayami

\section{PENDAHULUAN}

Tahu sebagai salah satu makanan dari olahan kedelai yang terus berinovasi, mulai dari gorengan tahu yang di jual di pinggir jalan hingga sekarang digunakan pada menu-menu masakan di restoran besar. Masyarakat Indonesia kurang minat mengkonsumsi kacang kedelai langsung tanpa diolah, mereka lebih menyukai produk olahannya, salah satunya adalah tahu (BPS, 2010).

Usaha industri tahu yang berkembang dimasyarakat adalah industri rumah tangga dan industri kecil. Permasalahan pokok yang saat ini menghambat perkembangan industri kecil adalah (1) pengaruh modal kerja yang sangat minim, (2) kenaikan harga bahan baku yang digunakan dalam pembuatan tahu, (3) pemasaran untuk menyalurkan tahu dari produsen ke konsumen karena kurangnya informasi pasar terkait dengan pola permintaan konsumen. Selain itu kemampuan dalam strategi pemasaran pada industri rumah tangga ini masih kurang karena umumnya pengusaha tahu industri kecil kurang atau tidak mengetahui produk yang sedang gencar di pasaran. Bahkan terkadang pengusaha tidak mampu menghasilkan produk dengan mutu yang sesuai dengan tuntutan pasar, selera konsumen, dan kurang mampu memproduksi dalam jumlah yang besar dalam waktu cepat sehingga permintaan pasar tidak dapat dipenuhi. 
Situbondo merupakan sebuah kabupaten yang masih banyak mempunyai usaha agroindustri tahu khususnya di Desa Paowan Kecamatan Panarukan, salah satunya adalah UD. Haji Imam Buhori. UD. Haji Imam Buhori merupakan suatu usaha agroindustri tahu yang tetap stabil ketika bahan baku dan kenaikan bahan bakar minyak mengalami kenaikan, masih selalu mencapai target produksi setiap harinya bahkan kadang kekurangan produk akibat terlalu banyaknya permintaan dari konsumen, hal itu dibuktikan dari tetapnya jumlah produksi dan harga jual tahu yang diberikan oleh pengusaha tersebut serta makin meningkatnya jumlah pembeli/konsumen tahu yang datang langsung untuk membeli produk tahu dari UD. Haji Imam Buhori. UD.Haji Imam Buhori juga merupakan salah satu perusahaan tahu yang sudah cukup tua untuk usianya yang sampai sekarang masih tetap bertahan meskipun sudah banyak perusahaan lainnya yang memiliki peralatan dan perlengkapan lebih modern. Bila dilihat dari nilai ekonomisnya, kebutuhan akan tahu sangat tinggi setiap harinya. Karena tahu merupakan makanan yang enak bagi semua kalangan, banyak manfaat yang bisa diperoleh dari tahu baik dari segi kesehatan maupun ekonomis. Usaha pembuatan tahu dirasa memberikan kontribusi pendapatan yang baik bagi produsen dan memiliki nilai tambah yang tinggi karena permintaan tahu tidak pernah turun sehingga meningkatkan taraf hidup pengusaha serta banyak dari produsen ingin mengembangkan usaha untuk kedepannya melalui pemasaran yang optimal.

Dari permasalahan-permasalahan yang telah dikemukakan di atas, maka peneliti tertarik untuk melakukan penelitian lebih lanjut untuk menganalisis nilai tambah pada tahu sebagai produk olahan kedelai. Nilai tambah yang besar karena proses pengolahan didapat dari pengurangan nilai produk yang dihasilkan dengan biaya penunjang (Intermediate cost) tidak termasuk tenaga kerja manusia (Sudiyono, 2004). Menurut Manullang (1990), tenaga kerja di sini hanya berfungsi sebagai perantara bahan mentah menjadi produk olahan dan besar kecilnya tenaga kerja yang digunakan dalam proses produksi dianggap tidak mempengaruhi nilai produk olahan yang dihasilkan. 
Pengertian nilai tambah adalah pertambahan nilai suatu komoditi karena adanya input fungsional yang diberlakukan pada komoditi yang bersangkutan. Input fungsional tersebut berupa proses mengubah bentuk (from utility), memindahkan tempat (place utility), maupun menyimpan (time utility). Terdapat dua cara menghitung nilai tambah. Kedua cara tersebut adalah dengan menghitung nilai tambah selama proses pengolahan, serta dengan menghitung nilai tambah selama proses pemasaran. Dalam penelitian ini nilai tambah yang digunakan adalah nilai tambah pengolahan (Hayami, 1987).

Tujuan yang ingin dicapai dalam penelitian ini adalah untuk mengetahui besar nilai tambah yang diperoleh dari usaha pembuatan tahu pada UD.Haji Imam Buhori di Desa Paowan Kecamatan Panarukan.

\section{METODE PENELITIAN}

Penentuan daerah penelitian dilakukan secara sengaja (Purposive Method) yang dilaksanakan pada UD.Haji Imam Buhori di Desa Paowan Kecamatan Panarukan Kabupaten Situbondo.Metode penelitian yang digunakan adalah analisis diskriptif. Analisis Deskriptif yaitu suatu metode yang digunakan untuk menganalisa data dengan cara mendeskripsikan atau menggambarkan data yang telah terkumpul sebagaimana adanya tanpa bermaksud membuat kesimpulan yang berlaku untuk umum. (Sugiyono, 2015). Nilai tambah yang diperoleh pada usaha pembuatan tahu pada UD. Haji Imam Buhori di Desa Paowan dianalisis dengan metode hayami.

\section{HASIL DAN PEMBAHASAN}

\section{Pendapatan Usaha Pembuatan Tahu UD. Haji Imam Buhori}

Pendapatan diperoleh dari perhitungan selisih antara penerimaan dan biaya produksi. Jika nilai yang diperoleh adalah positif maka usaha tersebut memperoleh pendapatan dan jika nilai yang diperoleh adalah negatif maka usaha tersebut mengalami kerugian maka untuk memperoleh pendapatan maka jumlah penerimaan harus lebih besar dari total biaya. Adapun besarnya pendapatan usaha 
pembuatan tahu pada UD. Haji Imam Buhori di Desa Paowan Kecamatan Panarukan Kabupaten Situbondo dapat dilihat pada Tabel 1.

Tabel 1 Pendapatan Usaha Pembuatan Tahu Pada UD. Haji Imam Buhori Desa Paowan Kecamatan Panarukan

\begin{tabular}{cccc}
\hline No & Komponen & Jumlah/Bulan (Rp) & Jumlah/Hari (Rp) \\
\hline 1. & Penerimaan & 64.090 .000 & 2.465 .000 \\
2. & Total Biaya & 47.722 .301 & 1.835 .473 \\
3. & Pendapatan & 16.367 .699 & 629.527 \\
\hline
\end{tabular}

Berdasarkan Tabel 1 dapat dilihat bahwa untuk usaha pembuatan tahu pada UD. Haji Imam Buhori di Desa Paowan Kecamatan Panarukan, pendapatan usaha tahu sebesar Rp. 16.367.699,-/bulan. Hal ini karena penerimaan usaha tahu sebesar Rp. 64.090.000,-/bulan dan biaya usaha tahu sebesar Rp. 47.722.301,/bulan. Sedangkan pendapatan usaha tahu sebesar Rp. 629.527,-/hari. Hal ini karena penerimaan usaha tahu sebesar Rp. 2.465.000,-/hari dan biaya usaha tahu sebesar Rp. 1.835.473,-/hari. Penghitungan pendapatan merupakan hasil pengurangan antara total penerimaan dan total biaya produksi. Dari hasil pendapatan usaha tahu sebesar Rp. 16.367.699,-/bulan yang diperoleh pengusaha tahu UD. Haji Imam Buhori di Desa Paowan, jumlah kedelai yang diproduksi mencapai $5.200 \mathrm{~kg} /$ bulan dengan perolehan tahu mencapai 3.120papan/bulan dan perolehan ampas tahu mencapai 338 sak/bulan. Dengan demikian dapat disimpulkan bahwa pendapatan usaha pembuatan tahu pada UD. Haji Imam Buhori menguntungkan dengan melihat besaran pendapatan yang diperoleh.

Pendapatan yang diperoleh usaha pembuatan tahu pada UD. Haji Imam Buhori di Desa Paowan Kecamatan Panarukan merupakan pendapatan bersih selama usaha 1 bulan. Soekartawi (2011) menyatakan pendapatan bersih usaha merupakan selisih antara pendapatan kotor (penerimaan) usaha dengan pengeluaran total usaha (total biaya usaha). Penerimaan usaha pembuatan tahu pada UD. Haji Imam Buhori di Desa Paowan Kecamatan Panarukan diperoleh dari jumlah produksi tahu dan ampas tahu dikalikan harga jual selama 1 bulan. 
Pendapatan usaha pembuatan tahu pada UD. Haji Imam Buhori menguntungkan tidak mungkin lepas dari peranan pemasaran yang baik.

Usaha pembuatan tahu pada UD. Haji Imam Buhori di Desa Paowan Kecamatan Panarukan memiliki kualitas tahu yang bagus, pelayanan yang baik bila ada konsumen yang membeli. Promosi yang dilakukan adalah dengan melalui agen-agen penjualan dan percakapan orang yang sudah menjadi pelanggan yang datang langsung untuk membeli tahu ditempat produksi maupun membeli pada tenaga penjualan di pasar. Saluran pemasaran untuk usaha pembuatan tahu pada UD. Haji Imam Buhori di Desa Paowan Kecamatan Panarukan yang ada sudah dari produsen, agen sampai konsumen tergantung pangsa pasar yang ada dimulai dari produsen sampai konsumen dengan tujuan untuk meningkatkan penjualan dan cakupan pasar yang menjadi tempat penjualan sudah cukup besar yaitu pasar-pasar yang ada di Kecamatan Panarukan sampai Situbondo.

\section{Nilai Tambah Usaha Pembuatan Tahu UD. Haji Imam Buhori}

Analisis nilai tambah dilakukan pada periode rata-rata produksi per hari. Dasar perhitungan nilai tambah menggunakan satuan $\mathrm{kg}$ bahan baku (kedelai). Analisis nilai tambah ini dilakukan untuk mengetahui besarnya nilai tambah usaha pembuatan tahu. Analisis nilai tambah terdiri dari beberapa komponen utama pembentuk biaya produksi meliputi bahan baku, sumbangan input lain, tenaga kerja dan keuntungan untuk masing-masing komponen utama yang digunakan. Nilai faktor konversi dihitung berdasarkan pembagian antara jumlah output yang dihasilkan dengan jumlah input yang digunakan. Nilai faktor konversi yang dihasilkan dari usaha pembuatan tahu bernilai 0,6 menunjukkan bahwa tiap $1 \mathrm{~kg}$ bahan baku kedelai yang digunakan, akan menghasilkan output sebanyak 0,6 papan tahu. Tingkat harga output tahu merupakan penjualan tahu setiap hari. Harga output tahu adalah Rp. 20.000 dan nilai output produk tahu sebesar Rp $12.000,-$. 
Nilai tambah usaha pembuatan tahu di daerah penelitian, dihitung dengan menggunakan model perhitungan hayami. Perhitungan nilai tambah dilakukan dengan melihat berbagai komponen yang mempengaruhi dalam perhitungan, antara lain sumbangan input lain dan harga bahan baku. Selain nilai tambah, model perhitungan hayami juga menganalisis pendapatan tenaga kerja, keuntungan pengusaha, serta dapat melihat margin yang diperoleh dari usaha pembuatan tahu tersebut. Secara rinci, perhitungan nilai tambah dengan menggunakan metode hayami berdasarkan data yang diperoleh dari lapangan dilihat pada Tabel 2 berikut :

Tabel 2. Rata-rata Nilai Tambah Usaha Pembuatan Tahu Pada UD. Haji Imam Buhori Di Desa Paowan Kecamatan Panarukan.

\begin{tabular}{lr}
\hline \multicolumn{1}{c}{ Variabel } & Nilai \\
\hline I. Output, Input dan Harga & 120 \\
\hline 1. Output (Papan/Hari) & 200 \\
2. Bahan baku (Kg/Hari) & 5 \\
3. Tenaga kerja (HKP/Hari) & 0,6 \\
4. Faktor konversi (1:2) & 0,025 \\
5. Koefisien tenaga kerja (3:2) & 20.000 \\
6. Harga output (Rp/ Papan) & 52.000 \\
7. Upah rata-rata tenaga kerja (Rp/HKP) & 7.500 \\
\hline II. Pendapatan dan Keuntungan & \\
8. Harga bahan baku (Rp/ Kg) & 2.167 \\
9. Harga input lain (Rp/Papan) & 567 \\
a. Tenaga kerja & 54 \\
b. Biaya penunjang & 2.788 \\
c. Biaya penyusutan & 12.000 \\
$\quad$ Total harga input lain & 1.712 \\
10. Nilai output (Rp/ Kg) & 14,27 \\
11. a. Nilai tambah (Rp/ Kg) & 1.300 \\
b. Rasio nilai tambah (\%) & 75,93 \\
12. a. Imbalan tenaga kerja (Rp/ Kg) & 412 \\
b. Bagian tenaga kerja (\%) & 3,43 \\
\hline 13. a. Keuntungan (Rp/ Kg) & 4.500 \\
b. Tingkat keuntungan (\%) & 28,89 \\
\hline III.Balas Jasa Pemilik Faktor Produksi & 61,96 \\
\hline 14. Marjin (Rp/ Kg) & 9,16 \\
\hline a. Pendapatan tenaga kerja (\%) & \\
b. Sumbangan input lain (\%) & \\
c. Keuntungan perusahaan (\%) & \\
\hline
\end{tabular}




\section{Imbalan dan Penggunaan Tenaga Kerja}

Tenaga kerja yang digunakan oleh usaha pembuatan tahu UD. Haji Imam Buhori adalah tenaga kerja langsung. Hari kerja dihitung dengan mengalikan waktu kerja dengan jumlah tenaga kerja dan dibagi 8. Satu hari kerja yang digunakan adalah 8 jam.

Koefisien tenaga kerja didapat dari hasil pembagian antara nilai input tenaga kerja dengan input bahan baku. Pengusaha pembuatan tahu UD. Haji Imam Buhori koefisien tenaga kerja sebesar 0,025 HKP per kg. Artinya pengusaha pembuatan tahu UD. Haji Imam Buhori memerlukan waktu 0,2 jam atau 12 menit untuk menghasilkan satu papan tahu. Hal ini menunjukkan bahwa pengusaha pembuatan tahu UD. Haji Imam Buhori yang ada di Desa Paowan memerlukan waktu yang cepat untuk menghasilkan satu papan tahu.

Imbalan tenaga kerja diperoleh dari hasil perkalian antara upah rata-rata tenaga kerja per HKP dengan koefisien tenaga kerja. Imbalan ini diberikan atas keseluruhan proses produksi setiap papan tahu dari mulai pencucian sampai pemotongan. Imbalan untuk tenaga kerja pada pengusaha pembuatan tahu UD. Haji Imam Buhori sebesar Rp 1.300 per papan atau 75,93\% dari nilai tambah produksi tahu. Artinya setiap Rp 100 per papan nilai tambah akan memberikan pendapatan tenaga kerja sebesar $\mathrm{Rp} 75,93$ per $\mathrm{kg}$.

\section{Distribusi Nilai Tambah}

Distribusi nilai tambah terhadap pendapatan tenaga kerja dan keuntungan dapat dilihat pada Tabel 3. Distribusi nilai tambah terhadap pendapatan tenaga kerja. Imbalan tenaga kerja menunjukkan jumlah pendapatan rata-rata yang diterima tenaga kerja untuk kegiatan produksi setiap satu papan tahu. Imbalan tenaga kerja tergantung dari jumlah hari orang kerja untuk dapat memproduksi satu papan tahu. 
Tabel 3 Distribusi Nilai Tambah Terhadap Imbalan Tenaga Kerja dan Keuntungan.

\begin{tabular}{lrr}
\hline \multirow{2}{*}{ Faktor Produksi } & \multicolumn{2}{c}{ Usaha Pembuatan Tahu } \\
\cline { 2 - 3 } & Nilai $(\mathbf{R p})$ & \% \\
\hline Imbalan Tenaga Kerja & 1.300 & 75,93 \\
Keuntungan & 412 & 3,43 \\
\hline Nilai Tambah & 1.712 & 14,27 \\
\hline
\end{tabular}

Tabel 3 menunjukkan bahwa nilai tambah dari usaha pembuatan tahu pada UD. Haji Imam Buhori sebesar Rp 1.712, per papan, jadi bila dikalikan maka nilai tambah dalam sehari yang apabila produksi mencapai 120 papan akan mendapatkan sebesar Rp. 205.440, perhari dengan rasio nilai tambah pembuatan tahu yaitu sebesar 14,27\%. Hal ini berarti bahwa setiap satu kilo kedelai yang digiling dan diproduksi pada UD. Haji Imam Buhori akan menghasilkan nilai tambah berupa produk olahan tahu yang mempunyai nilai sebesar Rp. 1.712,- .

Keuntungan merupakan selisih antara nilai tambah dengan pendapatan tenaga kerja. Keuntungan dari distribusi nilai tambah pengusaha pembuatan tahu yaitu sebesar Rp. 412 per papan, jadi bila dikalikan maka keuntungan pengusaha dalam sehari yang apabila produksi mencapai 120 papan akan mendapatkan sebesar Rp. 49.440, perhari.

\section{PENUTUP}

Berdasarkan perumusan masalah, tujuan penelitian, hipotesis, hasil penelitian dan pembahasan, maka dapat disimpulkan nilai tambah yang diperoleh pengusaha dalam produksi tahu sebesar Rp 1.712,- per papan tahu, keuntungan pengusaha dalam produksi tahu sebesar Rp 412,- per papan tahu dan sisanya sebesar Rp 1.300 per papan tahu merupakan imbalan tenaga kerja.

\section{DAFTAR PUSTAKA}

Badan Pusat Statistik. 2010. Pola Konsumsi Penduduk Di Indonesia Tahun 2010. Jakarta.

Hayami, et. al. 1987.Agricultural Marketing and Processing in Upland Java. A Perspective From A Sunda Village. CGPRT, Bogor 
Manullang, K. 1990. Pengukuran Produktivitas Dengan Metode Nilai Tambah. Pusat Produktivitas Nasional, Jakarta.

Sudiyono, A. 2004. Pemasaran Pertanian. UMM - press. Malang

Sugiyono. 2015. Metode Penelitian Kuantitatif, Kualitatif dan $R \& D$. Alfabeta.Bandung 